\title{
The Effect of Blending Ratio and Cooking Temperature on the Quality of Weaning Foods Preparation from Bulla, Chickpea and Banana Flour
}

\author{
Gashaw Abebaw Tsegaye, Solomon Duguma \\ Department of Food Process Engineering, Wolkite University, Wolkite, Ethiopia \\ Email address: \\ gashaw11abebaw@gmail.com (G. A. Tsegaye)

\section{To cite this article:} \\ Gashaw Abebaw Tsegaye, Solomon Duguma. The Effect of Blending Ratio and Cooking Temperature on the Quality of Weaning Foods \\ Preparation from Bulla, Chickpea and Banana Flour. Science Research. Vol. 8, No. 2, 2020, pp. 45-51. doi: 10.11648/j.sr.20200802.13
}

Received: January 17, 2020; Accepted: February 28, 2020; Published: April 28, 2020

\begin{abstract}
In this work, ready-to-eat weaning foods were formulated from cereal (chickpea), plant (banana), indigenous family (bulla). Legumes including chickpeas are important crops because of their nutritional quality. They are rich sources of protein and the aim of this study was to develop value added weaning food made by supplementation of chickpea flour, banana flour \& bulla flour The purpose of this study was to evaluate the effect of blending ratio and cooking temperature on quality of weaning food on Proximate composition, functional properties was done on seven different blending proportion of chickpea, banana, bulla before the development of weaning porridge then to conduct sensory evaluation by nine hedonic scale points. The result showed that moisture content range from $(2.68-8.11 \%)$, ash content range from $(8.01-11.21 \%)$. The functional analysis showed that water absorption capacity range from $(1.12-1.84 \%)$, oil absorption capacity $(1.4-2.09 \%)$, dispersibility (67.67-84.34\%), bulk density (0.63-0.73\%). The sensory evaluation showed mean scores range: color (4.76 - 6.39), appearance (4.90-6.23), aroma (4.26-6.51), texture (5.11- 5.93), taste (4.89-6.41), overall acceptability (5.26-6.73). Likewise the sensory evaluation shows that significant differences at $\mathrm{P}>0.05$ were observed for sensory attributes of color, texture, aroma, taste and overall acceptability in chickpea supplemented weaning food up to $10 \%$ chickpea flour addition. The weaning food prepared with the optimized mixture had high protein quality and digestibility and could be used to support the growth of infants.
\end{abstract}

Keywords: Weaning Food, Blending, Functional Properties, Bulla \& Chickpea

\section{Introduction}

Weaning refers to introduction of food other than mother's milk or complete Discontinuation of breast milk or introduction of solids to diet. Generally the term Weaning is used to denote the process in which infant changes from breast milk to mix. Diet [1]. It is the process of expanding the diet to include food and drinks other than breast milk or infant formula as it is the period of infant vulnerability [2]. It represents a period of dietary transition, just when nutritional requirements for growth and brain development are high. Observations of traditional Child feeding practices in many developing countries reveal that, weaning period is the whole period, during which breast milk is being replaced by other foods, usually starts when infant is 4-6 months old and is expected up to the age of two to three years.

Protein energy malnutrition is an important nutritional deficiency condition that often occurs during the critical transitional phase of weaning infants, crippling their physical and mental growth. This could be due to progressive decline in the incidence of breast feeding observed during the last 2530 years. This condition can be prevented to a large extent by introducing weaning foods of good quality and quantity at right proportion and at right stage [3]. In most developing countries of the world including Ethiopia, where acute shortage of protein is a problem, the occurrence of proteinenergy malnutrition (PEM), especially among children and adolescents is common [4].

Thus complementary feeding begins when breast milk alone is no longer sufficient to meet the nutritional requirements of infants and therefore other foods and liquids are needed along with breast milk. Different ingredients from different sources have been utilized in the formulation of weaning food to meet the requirements of the nutrients. A 
high proportion of the nursing mothers used local ingredients to formulate weaning foods for their babies.

The nutritional compositions of these foods are high quality and suitable as weaning foods, particularly for infants of low income parents who are unable to access commercial weaning foods [5]. Attempts have been made to utilize the ingredients like chickpea, Banana flour and bulla in waning food formulation.

The main challenge that consumers face in their daily menu is that the shortage of protein minerals and vitamins. Most of our baked products are carbohydrate rich but less in protein, minerals and vitamins. In order to produce protein, vitamin and minerals rich products, it is essential to supplement the flours of these products with bulla, banana and chickpea flour. Ethiopia has a considerable chickpea production capacity [6]. However chickpea is underutilized crop in Ethiopia and the same is true for bulla and banana. In addition to using in such traditional foods, it is also better to develop food products from chickpea, banana and bulla. Thus the utilization of these flours as ingredient in porridge products was create new market for the demand of protein, energy and mineral rich products and overcomes the problems stated above. In addition to this no publishing information is available as to which traditional processing methods are optimizing to reduce the effects of the cooking temperature and blending ratio factors to increase availability of the nutrients. In addition, food composition data are need in order to assess foods to promote for health purposes, evaluate the diet, establish locally relevant dietary guidelines, carry out research on the effect of cooking temperature and blending ratio on quality and nutritional contents of food [7].

\section{Literature Review}

\subsection{Bulla}

Ensetventricosum (Welw.) Chessman, commonly known as Enset, is a monocarp perennial herb originated in Ethiopia. Geographically distributed as a wild species in many parts of Sub-Saharan Africa and Asia, enset is cultivated only in its native indigenous farming systems of South and SouthWestern Ethiopia. In fact in Ethiopia, E. ventricosum is arguably the most important crop contributing to food security and rural livelihoods for about 1/4 (20 million people) of the country's population [8]. It is a multipurpose plant with a range of utilities including food, feed, construction and medicinal uses [9]. Moreover, enset cultivation improves soil by permanent soil tillage due to its high demands to soil fertility and soil structure [10]

\subsection{Health Benefits of Bulla}

The enset and its products are used for different nutritional, medical and non-nutritional purposes. The main food product of enset is the starch in the stem and pseudo stem. Koch is the fermented product of these starchy parts and can be baked like bread. These edible products of the enset plant have to be stored for several weeks in order to ferment, and can be stored for several years [11]. Bullais made by dehydrating the juice collected during the decortications of the stem and pseudo stem. The main difference between kocho and bulla is in the fiber content. Bulla consists mainly of refined carbohydrates with very low fiber content and, depending on the duration of fermentation, is less sour than kocho [12]. The preferred use of bulla is as a complementary food, and as a special food given to mothers after delivery, mainly prepared in the form of porridge. The nutrition department of the Attat Hospital in the project area successfully uses bulla as a staple food, combined with other protein, fat and micronutrient rich foods, in therapy of severely malnourished children [13].

\subsection{Banana}

Banana (Musa paradisiaca, family Musaceae) is a central fruit crop of the tropical and subtropical regions of the world grown on about 8.8 million hectares [14]. It is possibly the world's oldest cultivated crop [10]. As a diet, banana is an affluent source of carbohydrate with calorific value of 67 calories per $100 \mathrm{~g}$ fruit and is one of the most well-liked and widely traded fruits across the world [14]. It is one of the tallest herbaceous plants with a pseudo stem. Its tough treelike pliable stem is composed of the sheathing twisting leaf bases, which contains fibers of sufficient strengths to keep the tree upright. In different countries, about 300 varieties of bananas are grown, of which a vast majority are grown in tropical Asia [15].

\subsection{Health Benefits of Banana}

Hundred grams of ripe Banana provides approximate 116 Kcal energy that makes it a supplementary staple food. Banana has relatively less proteins compared to cereals, absence of other protein rich foods in the diet can cause protein deficiency in people depending mostly on Banana as staple food and it is cooked or ripe Banana are easily digested. Banana is a fair source of Vitamin B, Calcium and also contains about $20 \%$ sugars [16].

\section{Materials and Methods}

\subsection{Experimental Site}

These experiments were done at Wolkite University College of Engineering and Technology in Food Process Engineering Laboratory.

\subsection{Experimental Materials}

The raw materials was collected from Gurage Zone in Wolkite town, Ethiopia and the research were conducting to have seen the effect of blending ratio, cooking temperature and time on quality weaning food preparing from bulla, chick pea and banana flour by done all the experiments

\subsection{Experimental Design}

The product was produced in triplicate and evaluating 
under random complete block design (RCBD).

Table 1. Experimental Plan.

\begin{tabular}{llll}
\hline Blending Ratio & \multicolumn{3}{l}{ Cooking Temperature } \\
\hline & T1 & T2 & T3 \\
B1 & B1T1 & B1T2 & B1T3 \\
B2 & B2T1 & B2T2 & B2T3 \\
B3 & B3T1 & B3T2 & B3T3 \\
B4 & B4T1 & B4T2 & B4T3 \\
B5 & B5T1 & B5T2 & B5T3 \\
B6 & B6T1 & B6T2 & B6T3 \\
Control & CT1 & CT2 & CT3 \\
\hline
\end{tabular}

Where: - $\mathrm{B}=\mathrm{Blending}$ ratio, $\mathrm{C}=\mathrm{C}$ Control, and $\mathrm{T}=$ Temperature

Note:-B1: chickpea, banana and bulla, 50:30:20, B2: chickpea, banana and bulla, 35:15:50, B3: chickpea, banana and bulla, 20:10:70, B4: chickpea, banana and bulla, 30:10:60, B5: chickpea, banana and bulla, 70:15:15, B6: chickpea, banana and bulla, 25:20:55, C: chickpea, banana and bulla, 0:0:100, $\mathrm{T} 1: 60^{\circ} \mathrm{C}, \mathrm{T} 2: 70^{\circ} \mathrm{C}, \mathrm{T} 3: 80^{\circ} \mathrm{C}$ respectively [17]

\subsection{Statistical Analysis}

Data was analyzed by the analysis of variance (ANOVA) procedures using statically analysis of software (SAS) for windows version 9.0. Least significant differences (LSD) are using for Fisher mean comparison tests. Significance is accepting at $(\mathrm{P}<0.05)$.

\section{Results and Discussions}

In this research, different functional properties of composite flours were analyzed with using standard procedures (Table 2). Functional properties or characteristics are the intrinsic physico-chemical properties that reflect the complex interaction between the composition, structure, confirmation and physico-chemical properties of protein and other A food components and the nature of environment in which these are associated and measured [18]. The effect of incorporation proportions of different flours on the functional properties of composite flours are discussed as follows [19].

Table 2. Functional Property of Composite Flour.

\begin{tabular}{lllll}
\hline Treatment & WAC $(\mathbf{g} / \mathbf{g})$ & $\begin{array}{l}\text { OAC } \\
(\mathbf{m l} / \mathbf{g})\end{array}$ & $\begin{array}{l}\text { Dispersability } \\
(\mathbf{m l})\end{array}$ & BD $(\mathbf{g} / \mathbf{m l})$ \\
\hline B1 & $1.72 \pm 0.06^{\text {ba }}$ & $1.49 \pm 0.06^{\mathbf{b}}$ & $72 \pm 2^{\mathbf{d}}$ & $0.67 \pm 0.01^{\mathbf{b}}$ \\
B2 & $1.45 \pm 0.21^{\text {ba }}$ & $2.09 \pm 0.18^{\mathbf{a}}$ & $77.67 \pm 1.52^{\mathbf{b}}$ & $0.71 \pm 0.01^{\mathbf{a}}$ \\
B3 & $1.55 \pm 0 ; .13^{\text {ba }}$ & $2.09 \pm 0.28^{\mathbf{a}}$ & $78.34 \pm 1.52^{\mathbf{b}}$ & $0.71 \pm 0.01^{\mathbf{a}}$ \\
B4 & $1.75 \pm 0.78^{\text {ba }}$ & $1.54 \pm 0.13^{\mathbf{b}}$ & $74.34 \pm 1.15^{\text {cd }}$ & $0.63 \pm 0.01^{\mathbf{c}}$ \\
B5 & $1.84 \pm 0.33^{\mathbf{a}}$ & $0.99 \pm 0.04^{\mathbf{c}}$ & $67.67 \pm 1.53^{\mathbf{e}}$ & $0.67 \pm 0.02^{\mathbf{b}}$ \\
B6 & $1.27 \pm 0.26^{\text {ba }}$ & $1.06 \pm 0.13^{\mathbf{c}}$ & $76.67 \pm 2.52^{\text {cb }}$ & $0.73 \pm 0.02^{\mathbf{a}}$ \\
Control & $1.12 \pm 0.35^{\mathbf{b}}$ & $1.4 \pm 0.07^{\mathbf{b}}$ & $84.34 \pm 1.53^{\mathbf{a}}$ & $0.72 \pm 0.01^{\mathbf{a}}$ \\
LSD & 0.66 & 0.26 & 3.03 & 0.02 \\
CV & 24.67 & 9.91 & 2.28 & 1.6 \\
\hline
\end{tabular}

Note: $\mathrm{WAC}=$ Water absorption Capacity, OAC $=$ Oil absorption capacity, $\mathrm{BD}=$ Bulk Density, within a column, values with different superscript letters have significant $(\mathrm{P}<0.05)$ differences.

\subsection{Water Absorption Capacity of Flour}

The measured water absorption capacity of composite flours is presented in Table 2. The value was water absorption capacity ranged between 1.12 to $1.84 \mathrm{~g} / \mathrm{g}$ for all treatment flours. There is significant difference among the treatment at $(\mathrm{P}<0.05)$. The Water absorption capacity was observed highest in $\mathrm{B}_{5}(1.84 \mathrm{~g} / \mathrm{g})$ and the lowest in $\mathrm{C}(1.12$ $\mathrm{g} / \mathrm{g})$. While composite flours $\mathrm{B}_{20}, \mathrm{~B}_{50}, \mathrm{~B}_{70}, \mathrm{~B}_{60}, \mathrm{~B}_{15}$ and $\mathrm{B}_{55}$ bulla had 1.72, 1.45, 1.55, 1.75, 1.84, 1.27 and $1.12 \mathrm{~g} / \mathrm{g}$ water absorption capacity respectively. From the present study, chickpea flour had highest water absorption capacity $(1.84 \mathrm{~g} / \mathrm{g})$. The result suggests that addition of banana and chickpea flour to bulla affected the amount of water absorption. This could be due to molecular structure of the banana and chickpea which inhibited water absorption, as could be seen from the lower values of water absorption capacity with increase in proportions of other flours to bulla [20]. The increase in the water absorption capacity has always been associated with increase in the amylose leaching and solubility, and loss of starch crystalline structure [21]. The flour with high water absorption may have more hydrophilic constituents such as polysaccharides. Protein has both hydrophilic and hydrophobic nature and therefore they can interact with water in foods. The observed variation in different flours may be due to different protein concentration, their degree of interaction with water and conformational characteristics [22].

\subsubsection{Oil Absorption Capacity of Flour}

Before preparation of composite flour, oil absorption capacity of bulla, banana, and chickpea flour were analyzed and found as $1.4,1$, and $2 \mathrm{ml} / \mathrm{g}$, respectively. The measured oil absorption capacities of flours are presented in Table 2. The values were $1.49,2.09,2.09,1.54,0.99,1.06$ and $1.4 \mathrm{ml} / \mathrm{g} \mathrm{B} 1$, B2, B3, B4, B5, B6 and control respectively. There is significant difference among the treatment at $(\mathrm{P}<0.05)$. The composite flours $\left(\mathrm{B}_{2}\right.$ and $\left.\mathrm{B}_{3}\right)$ had highest oil absorption capacity $\left(2.09 \mathrm{ml} / \mathrm{g}\right.$ for both) and lowest for $\mathrm{B}_{5}(0.99 \mathrm{ml} / \mathrm{g})$ as compared to bulla $(1.4 \mathrm{ml} / \mathrm{g})$ [23]. It is clear that the oil absorption capacities of composite flours $\left(\mathrm{B}_{2}\right.$ and $\left.\mathrm{B}_{3}\right)$ increased with increase in the proportion of other flours. The presence of high fat content in flours might have affected adversely the oil absorption capacities of the composite flours. The oil absorption capacities were found to be insignificant to each other at $\mathrm{P}<0.05$ level of significance [24]. Therefore the possible reason for increase in the oil absorption capacities of composite flours after incorporation of chickpea flour. However, the flours in the present study are potentially useful in structural interaction in food especially in flavor retention, improvement of palatability and extension of shelf life particularly in bakery or meet products where fat absorption is desired [25]. The major chemical component affecting oil absorption capacities is protein which is composed of both hydrophilic and hydrophobic parts. Non-polar amino acid side chains can form hydrophobic interaction with hydrocarbon chains of lipids [26].

\subsubsection{Bulk Density of Flour}

The measured bulk density of composite flours is 
presented in Table 2. The bulk densities of flours ranged from $0.63 \mathrm{~g} / \mathrm{ml}$ to $0.73 \mathrm{~g} / \mathrm{ml}$. The highest bulk density was observed $\mathrm{B}_{6}, \mathrm{C}, \mathrm{B}_{3}$ andB $\mathrm{B}_{2}$ flour followed by $\mathrm{B}_{1}$ flour $(0.67 \mathrm{~g} / \mathrm{ml}), B_{5}$ flour $(0.67 \mathrm{~g} / \mathrm{ml})$ and lowest for $B_{4}(0.63 \mathrm{~g} / \mathrm{ml})$. The present study revealed that bulk density depends on the particle size and initial moisture content of flours [27]. Bulk density of composite flour increased with increase in the incorporation of different flours with bulla. It is clear that decreased the proportion of bulla increase the bulk density of composite flours. The high bulk density of flour suggests their suitability for use in food preparations. On contrast, low bulk density would be an advantage in the formulation of complementary [28]. Therefore, present study suggests that highest bulk density of composite flour $\left(\mathrm{B}_{6}, \mathrm{C}, \mathrm{B}_{3}\right.$ and $\left.\mathrm{B}_{2}\right)$ suggests its suitability to be used as thickener in food products and for use in food preparation since it help to reduce paste thickness which is an important factor in convalescent and child feeding. Bulk density of composite flours increased significantly with increase in the incorporation of banana and chickpea flour with bulla [6].

\subsubsection{Dispersability of Flour}

Before preparation of composite flour, Dispersability of bulla, banana, and chickpea flour were analyzed and found as 84, 74, and $64 \mathrm{ml}$, respectively. The measured Dispersability of composite flours is presented in Table 3. Dispersability which ranged from $67.67 \mathrm{ml}$ to $84.34 \mathrm{ml}$ increased as $\mathrm{B}_{5}$ and control level increased. As the chickpea increases the composite flour of Dispersability increased. Dispersability is an index that measures how well flour or flour blends can be rehydrated with water [29]. All the flour blends have relatively high dispersibility signifying that they will reconstitute easily to fine consistent dough or pudding during mixing [30].

Table 3. Proximate Composition of Flour.

\begin{tabular}{lll}
\hline Treatment & M.C $(\%)$ & Ash $(\%)$ \\
\hline B1 & $2.68 \pm 0.04^{\mathrm{e}}$ & $8.01 \pm 0.1^{\mathbf{f}}$ \\
B2 & $3.84 \pm 0.15^{\mathbf{c}}$ & $8.7 \pm 0.06^{\mathrm{e}}$ \\
B3 & $4.33 \pm 0.11^{\mathbf{b}}$ & $9.45 \pm 0.07^{\mathbf{d}}$ \\
B4 & $3.11 \pm 0.09^{\mathbf{d}}$ & $8.53 \pm 0.01^{\mathrm{e}}$ \\
B5 & $2.09 \pm 0.07^{\mathbf{f}}$ & $11.21 \pm 0.19^{\mathrm{a}}$ \\
B6 & $4.4 \pm 0.1^{\mathbf{b}}$ & $10.28 \pm 0.32^{\mathbf{c}}$ \\
Control & $8.11 \pm 0.1^{\mathrm{a}}$ & $10.72 \pm 0.29^{\mathbf{b}}$ \\
LSD & 0.18 & 0.33 \\
CV & 2.48 & 1.98 \\
\hline
\end{tabular}

Note: M.C=Moisture content, $\mathrm{LSD}=$ Least Significant Difference, $\mathrm{CV}=$ Coefficient of variance

Within a column, values with different superscript letters have significant $(\mathrm{P}<0.05)$ differences.

\subsubsection{Moisture Content of Flour}

Before preparation of composite flour, moisture content of bulla, banana, and chickpea flour were analyzed and found as
$8.11 \%, 1 \%$, and $2.1 \%$, respectively. The moisture content (d.b.) for bulla and composite flours are presented in Table 3. This ranged from $2.09 \%$ to $8.11 \%$ depending upon the blending ratio. The moisture content of composite flours i.e. $\mathrm{B}_{1}(2.68 \%), \mathrm{B}_{2}(3.84 \%), \mathrm{B}_{3}(4.33 \%), \mathrm{B}_{4}(3.11 \%), \mathrm{B}_{5}(2.09 \%)$, $\mathrm{B}_{6}(4.4 \%)$ and $\mathrm{C}(8.11 \%)$ were also determined. From the Table 4 , it is clear that the moisture content of composite flours decreased with increase in proportions of other flours [31]. The moisture content of composite flour was highly affected by blending of banana and chickpea flours. The highest moisture content was observed for Control (8.11\%) and lowest for $\mathrm{B}_{5}(2.09 \%)$ in the composite flours. The study revealed that moisture content of composite flours decreased with decrease in proportions of bulla [32].

\subsubsection{Ash Content of Flour}

In this experiment the ash content was in the order of $\mathrm{B}_{5}>$ $\mathrm{C}>\mathrm{B}_{6}>\mathrm{B}_{3}>\mathrm{B}_{2}>\mathrm{B}_{4}>\mathrm{B}_{1}$ with value of $11.21 \%, 10.72 \%$, $10.28 \%, 9.45 \%, 8.7 \%, 8.53 \%$, and $8.01 \%$ respectively. The high ash content is $\mathrm{B}_{5}$ indicates that high mineral content compared with other blend proportions. So $\mathrm{B}_{5}$ is best ratio based on their ash content value it is good for infant formulation than that of control. Ash content is a measure of the total amount of minerals present within a food [33]. The higher the ash content, the higher the minerals content in the food. Ash is the inorganic residue remaining after the water and organic matter have been removed by heating in the presence of oxidizing agents, which provides mineral content, a measure of the total amount specific inorganic components within a food. The ash content of each food will be different due to the different mineral content in each food and the origin of the food [34].

\subsection{Sensory Analysis of Porridge}

The study was conducted to determine the acceptability of porridge developed from various proportions of chickpea, bulla and banana flour. Porridge made from the composite flours was evaluated by 15 untrained panelists. The panelist evaluated the products based on how much they liked the appearance, color, aroma, taste, texture and overall acceptability. A 9-point hedonic scale (1 representing dislike extremely and 9 representing like extremely) was used for the evaluation. Panelists were provided with a piece of unsalted porridge and still water to refresh their palate after tasting each sample. Porridge made from bulla was used as a control [35]. The data obtained from the various experiments were recorded during the study and were subjected to statistical analysis as per method of "Analysis of Variance" by factorial Randomized Complete Block Design (factorial RCBD). The significant difference between the means was tested against the critical difference at 5\% level of significance [20]. Statically analysis of soft ware (SAS) was used for analyze the recorded data. Results on the mean scores for the sensory attributes of the porridge [36]. 
Table 4. Sensory Analysis of porridge.

\begin{tabular}{|c|c|c|c|c|c|c|}
\hline Treatment & Color & Appearance & Aroma & Texture & Taste & OverallAcc \\
\hline B1T1 & $5.13 \pm 0.11^{\text {ba }}$ & $6.09 \pm 0.59^{\text {ba }}$ & $5.71 \pm 0.57^{\text {bdac }}$ & $5.42 \pm 0.90^{\mathrm{a}}$ & $5.68 \pm 0.94^{\mathrm{a}}$ & $6.32 \pm 0.50^{\mathrm{bac}}$ \\
\hline B1T2 & $5.37 \pm 0.15^{\text {ba }}$ & $5.57 \pm 0.33^{\text {ba }}$ & $6.11 \pm 1.25^{\mathrm{bac}}$ & $5.54 \pm 0.30^{\mathrm{a}}$ & $5.56 \pm 0.71^{\mathrm{d}}$ & $6.42 \pm 0.58^{\mathrm{bac}}$ \\
\hline B1T3 & $5.55 \pm 1.33^{\text {ba }}$ & $5.92 \pm 0.88^{\text {ba }}$ & $5.81 \pm 1.11^{\text {bdac }}$ & $5.52 \pm 1.07^{\mathrm{a}}$ & $6.41 \pm 0.96^{\mathrm{d}}$ & $6.73 \pm 0.62^{\mathrm{a}}$ \\
\hline $\mathrm{B} 2 \mathrm{~T} 1$ & $5.59 \pm 0.35^{\text {ba }}$ & $4.98 \pm 0.06^{\mathrm{ba}}$ & $5.46 \pm 0.30^{\text {bdac }}$ & $5.52 \pm 0.41^{\mathrm{a}}$ & $5.27 \pm 0.64^{\mathrm{a}}$ & $5.53 \pm 0.41^{\mathrm{bc}}$ \\
\hline B2T2 & $5.90 \pm 1.04^{\mathrm{ba}}$ & $6.17 \pm 0.67^{\text {ba }}$ & $5.69 \pm 0.66^{\mathrm{bdac}}$ & $5.47 \pm 0.88^{\mathrm{a}}$ & $5.73 \pm 0.96^{\mathrm{d}}$ & $6.14 \pm 0.48^{\text {bac }}$ \\
\hline В2Т3 & $5.25 \pm 1.22^{\text {ba }}$ & $5.19 \pm 1.04^{\text {ba }}$ & $5.05 \pm 0.48^{\mathrm{dec}}$ & $5.43 \pm 1.05^{\mathrm{a}}$ & $5.52 \pm 0.94^{\mathrm{d}}$ & $5.33 \pm 0.58^{c}$ \\
\hline B3T1 & $5.19 \pm 0.21^{\text {ba }}$ & $5.54 \pm 0.89^{\text {ba }}$ & $5.08 \pm 0.33^{\mathrm{dec}}$ & $5.50 \pm 0.58^{\mathrm{a}}$ & $5.37 \pm 0.69^{\mathrm{d}}$ & $5.33 \pm 0.63^{\mathrm{bc}}$ \\
\hline B3T2 & $5.91 \pm 1.69^{\text {ba }}$ & $5.73 \pm 0.71^{\text {ba }}$ & $5.32 \pm 1.15^{\text {bdec }}$ & $5.68 \pm 0.47^{\mathrm{a}}$ & $5.84 \pm 0.65^{\mathrm{a}}$ & $6.09 \pm 0.35^{\text {bac }}$ \\
\hline В3Т3 & $5.36 \pm 0.32^{\text {ba }}$ & $5.61 \pm 0.50^{\text {ba }}$ & $5.95 \pm 0.71^{\mathrm{bdac}}$ & $5.20 \pm 0.19^{\mathrm{a}}$ & $6.03 \pm 0.59^{\mathrm{a}}$ & $5.84 \pm 1.17^{\mathrm{bac}}$ \\
\hline B4T1 & $5.52 \pm 0.44^{\text {ba }}$ & $6.23 \pm 0.33^{\mathrm{a}}$ & $6.32 \pm 0.32^{\text {ba }}$ & $5.36 \pm 1.29^{\mathrm{a}}$ & $6.30 \pm 0.82^{\mathrm{a}}$ & $6.42 \pm 0.99^{\mathrm{bac}}$ \\
\hline B4T2 & $6.39 \pm 0.92^{\mathrm{a}}$ & $5.03 \pm 0.58^{\text {ba }}$ & $5.66 \pm 0.38^{\text {bdac }}$ & $5.25 \pm 0.22^{\mathrm{a}}$ & $5.64 \pm 0.55^{\mathrm{a}}$ & $5.79 \pm 0.88^{\text {bac }}$ \\
\hline B4T3 & $5.56 \pm 0.72^{\text {ba }}$ & $5.57 \pm 0.75^{\text {ba }}$ & $6.51 \pm 0.57^{\mathrm{a}}$ & $5.82 \pm 0.44^{\mathrm{a}}$ & $6.08 \pm 0.96^{\mathrm{a}}$ & $6.04 \pm 0.90^{\mathrm{bac}}$ \\
\hline B5T1 & $6.11 \pm 0.36^{\text {ba }}$ & $5.44 \pm 0.89^{\text {ba }}$ & $5.04 \pm 0.42^{\mathrm{dec}}$ & $5.37 \pm 0.94^{\mathrm{a}}$ & $5.45 \pm 0.76^{\mathrm{d}}$ & $5.99 \pm 0.78^{\text {bac }}$ \\
\hline B5T2 & $5.69 \pm 0.52^{\text {ba }}$ & $4.92 \pm 0.62^{b}$ & $5.11 \pm 0.54^{\mathrm{dec}}$ & $5.08 \pm 0.52^{\mathrm{a}}$ & $5.37 \pm 0.55^{\mathrm{a}}$ & $5.46 \pm 0.44^{\mathrm{bc}}$ \\
\hline В5T3 & $5.71 \pm 0.71^{b a}$ & $5.41 \pm 0.38^{b a}$ & $5.36 \pm 0.60^{\text {bdec }}$ & $5.58 \pm 0.58^{\mathrm{a}}$ & $5.73 \pm 0.90^{\mathrm{d}}$ & $5.57 \pm 0.84^{\mathrm{bac}}$ \\
\hline B6T1 & $6.13 \pm 1.10^{\mathrm{a}}$ & $5.43 \pm 0.94^{\text {ba }}$ & $5.80 \pm 1.02^{\mathrm{bdac}}$ & $5.11 \pm 0.21^{\mathrm{a}}$ & $5.72 \pm 1.13^{\mathrm{d}}$ & $6.25 \pm 0.91^{\mathrm{bac}}$ \\
\hline B6T2 & $6.09 \pm 0.94^{\mathrm{ba}}$ & $5.74 \pm 1.05^{\text {ba }}$ & $5.89 \pm 0.60^{\mathrm{bdac}}$ & $5.77 \pm 0.70^{\mathrm{a}}$ & $6.07 \pm 1.18^{\mathrm{d}}$ & $6.42 \pm 1.00^{\mathrm{bac}}$ \\
\hline В6T3 & $5.58 \pm 0.49^{\text {ba }}$ & $5.05 \pm 0.99^{\text {ba }}$ & $5.53 \pm 0.51^{\text {bdac }}$ & $5.93 \pm 0.81^{\mathrm{a}}$ & $5.74 \pm 0.47^{\mathrm{d}}$ & $5.71 \pm 0.58^{\text {bac }}$ \\
\hline CT1 & $5.48 \pm 0.83^{\text {ba }}$ & $5.20 \pm 1.23^{\mathrm{ba}}$ & $5.71 \pm 0.87^{\text {bdac }}$ & $5.62 \pm 0.44^{\mathrm{a}}$ & $5.83 \pm 0.73^{\mathrm{d}}$ & $6.53 \pm 0.56^{\mathrm{ba}}$ \\
\hline $\mathrm{CT} 2$ & $4.76 \pm 0.28^{b}$ & $4.90 \pm 0.92^{\mathrm{b}}$ & $4.89 \pm 0.40^{\mathrm{de}}$ & $5.24 \pm 0.86^{\mathrm{a}}$ & $5.56 \pm 0.84^{\mathrm{d}}$ & $5.93 \pm 0.81^{\text {bac }}$ \\
\hline CT3 & $5.61 \pm 0.97^{\text {ba }}$ & $4.91 \pm 0.71^{b}$ & $4.26 \pm 0.47^{\mathrm{e}}$ & $5.45 \pm 1.02^{\mathrm{a}}$ & $4.89 \pm 1.09^{\mathrm{d}}$ & $5.26 \pm 0.60^{c}$ \\
\hline LSD & 1.35 & 1.14 & 1.13 & 1.28 & 1.31 & 1.20 \\
\hline $\mathrm{CV}$ & 14.63 & 14.11 & 12.45 & 14.21 & 10 & 12.25 \\
\hline
\end{tabular}

Color is very significant parameter in judging well porridge prepared. It doesn't only reflect the suitable raw material used for the preparation but also provides information about the formulation and quality of the product [37]. The mean score of porridge color was decreased from 6.39 to 4.76 as the level of bulla flour addition increased from $\mathrm{B}_{4} \mathrm{~T}_{2}$ to $\mathrm{CT}_{2}$ (Table 4). This indicates that supplementation of banana and chickpea with bulla up to $60 \%$ of cooking temperature at $70^{\circ} \mathrm{C}$ for porridge was acceptable with respect to color.

\subsubsection{Appearance}

The mean score of porridge appearance was decreased from 6.23 to 4.90 as the level of bulla flour addition increased from $\mathrm{B}_{4} \mathrm{~T}_{1}$ to $\mathrm{CT}_{2}$ (Table 4). This indicates that supplementation of banana and chickpea with bulla up to $60 \%$ of cooking temperature at $60^{\circ} \mathrm{C}$ for porridge was acceptable with respect to appearance [38].

\subsubsection{Aroma}

The mean aroma score of the porridge was significantly affected by blend proportion and the result shows that the aroma score decreased from 6.51 to 4.26 as the level of bulla flour addition increased in the porridge. Hence $60 \%$ bulla $\left(\mathrm{B}_{4} \mathrm{~T}_{3}\right)$ flour addition porridge was acceptable with respect to aroma [39].

\subsubsection{Texture}

The result shows that the mean texture score of bulla supplemented porridge was decreased from 5.93 to 5.11 with increasing bulla substitution. Consequently the porridge made by $55 \%\left(\mathrm{~B}_{6} \mathrm{~T}_{3}\right)$ of bulla addition resulted in porridge with other blend of such as banana and chickpea have better texture than the control porridge ratio [40].

\subsubsection{Taste}

Results of the study revealed that porridge made from $\mathrm{B}_{1} \mathrm{~T}_{3}$ flour were observed highest taste score of 6.41 followed by $\mathrm{B}_{4} \mathrm{~T}_{1}$ (6.30) while lowest for $\mathrm{CT}_{3}$ (4.89). Taste score decreased with increasing bulla in the formulation of porridge [41].

\subsubsection{Overall Acceptability}

The sensorial data for effect on overall acceptability of porridge are given in Table 4. Highest overall acceptability was scored for $\mathrm{B}_{1} \mathrm{~T}_{3}$ porridge (6.73) followed by $\mathrm{CT}_{1}$ (6.53) while lowest for control porridge by temperature difference $\mathrm{CT}_{3}$ (5.26) just after preparing and cooling [42]. Sensorial data revealed that overall acceptability of porridge increased with increasing incorporation of chickpea and banana flour with bulla in the formulation of porridge. In general, overall acceptability of porridge depends on the individual data of different sensory attributes like color, aroma, taste, appearance and texture. In case of composite flour porridge, overall acceptability was awarded highest for $\mathrm{B}_{1} \mathrm{~T}_{3}$ as compared to control porridge [43]. All porridge coincided in the range of like 'like slightly' to 'like very much' for porridge made from composite flours, while 'neither like nor dislike' to 'like moderately' for control porridge [44].

\section{Conclusions}

The study made an attempt to identify porridge formulations using chickpea, bulla and banana composite flours. The functional properties of bulla and composite flours such as water absorption capacity, oil absorption 
capacity, dispersibility and bulk density were increased with increase in the incorporation of other flours with bulla. The result showed that the addition of chickpea and banana flour to bulla in the proportion of 10 to $70 \%$ for each produced acceptable porridge and also functionality of the flour was not affected. Sensorial data revealed that Overall acceptability of porridge increased with increasing in the incorporation of banana and chickpea flour with bulla in the formulation of porridge. The porridge prepared with the flour ratio of 50: 30: 20 liked most of the panelists. But according to nutritional quality $\mathrm{B}_{5}$ ( 70 chickpea, 15 banana and 15 bulla) at temperature $70^{\circ} \mathrm{C}$ is better for infant food formulation. Incorporation of above flours to bulla would therefore be an effective method of cost reduction of porridge and other allied products and solving malnutrition problems in children in Ethiopia

\section{References}

[1] Temesgen, M. 2013. Nutritional Status of Ethiopian Weaning and Complementary Foods: A Review. 2: 621 doi: 10.4172/scientificreports.621

[2] Sajilta, G., Singhal R. S. and Kulkarni, P. R. 2002. Weaning foods: a review of the Indian Experience, Infants Food Nutr. Bull., 23: 208-226.

[3] Pawar, P. A. and Dhanvijay, V. P. 2007. Weaning foods: Anoverview. Beverage Food world. 34; 27-33.

[4] Yebeltal Jenberu. 2012. Consumption of vitamin A rich foods by children aged 6-23 months and Formulation of MaizeBased complementary porridge using orange fleshed sweet potato flour and bean in kachabira woreda, Southern Ethiopia. MSc Thesis, Hawasaa University, Hawasaa. 151 pp.

[5] Ijarotimi and Ogunsemore, 2007. Weaning foods and their impact on child-feeding practices among low-income Nigerian mothers. Food and Nuty Bull., 27 (4): 327-334 in Ethiopia," Journal of Agricultural Ecomonics 2 (3) (2360-798x), 031-040.

[6] Lesiapeto M. S. 2009. Factor associated with nutritional status of children aged 0-60 months residing in Eastern Cape and Kwazulu-Natal Provinces. MSc. Thesis, Pochefstroom Campus, North-West University, South Africa. 112 pp.

[7] Olayiwola I. O., Folarnmi F., Adebowale A., Onabanjo O. O., Sanni S. A. and Afolabi W. A. O. 2012. Nutritional Composition and Sensory Qualities of Cocoyam-Based Recipes Enriched with Cowpea Flour. Journal of Nutrition and Food Science. 2 (10): 1-6.

[8] World Bank. 2012. Infant and Young Child Feeding: World Bank Nutrition report.siteresources.worldbank.org/NUTRIT ION/Resources/Tool2-Chap5.pdf (Accessed on Jan, 2013).

[9] Helen W/Michael. 2010. Influence of Processing on Antinutrients and Production of some Value Added Finger Millet Based Products. MSc Thesis, Addis Ababa University, Addis Ababa. 115pp.

[10] Anigo K. M., Ameh D. A., Ibrahim S. \& Danbauchi S. S. 2010 Nutrient composition of complementary food gruels formulated from malted cereals, soybeans and groundnut for use in North-western Nigeria. African Journal of Food Science.
$4(3): 65-72$.

[11] Olango T. M., Tesfaye B., Catellani M., Pè M. E. 2014. Indigenous knowledge, use and on-farm management of enset (Enseteventricosum (Welw.) Chessman) diversity inWolaita, Southern Ethiopia. J. Ethnobiol. Ethnomed. 10: 41. 10.1186/1746-4269- 10-41, PMID: [PMC free article. Production crop data, Yams, 2010, Food and Agriculture Organization of the United Nations

[12] Annual report. (2012). McKnight CCRP 11-283, Enset bacterial wilt

[13] Mohapatra, D., Mishra, S. and Sutar, N. 2010. Banana and its by-product utilization: an overview Journal Scientific \& Industrial Research, 69: 323-329.

[14] Kumar, K. P. S., Bhowmik, D., Duraivel, S. and Umadevi, M. 2012. Traditional and medicinal uses of banana. Journal Pharmacognosy and Photochemistry, 1: 51-63.

[15] Kidane G., Abegaz, K., Mulugeta, A., and Singh, P., 2013. Nutritional Analysis of Vitamin A Enriched Bread from Orange Flesh Sweet Potato and Locally Available Wheat Flours at Samre Woreda, Northern Ethiopia. Current Research in Nutrition and Food Science. 1 (1): 49-57.

[16] Adebowale, A. R. A, S. A. Sanni and F. O. Oladapo, 2008. Chemical, functional and sensory Properties of instant yambread fruit flour. Niger. Food j., 26: 2-12.

[17] Aider, M., Sirois-Gosselin, M. and Boye, J. I. (2012). Pea, Lentil and Chickpea Protein Application in Bread Making. Journal of Food Research. 1 (4): 160-173.

[18] Abdelrahman, R. A., Mohammed, I. and Senge, B. (2011). Dynamic Rheological Properties of Chickpea and Wheat Flour Dough's. Journal of Applied Sciences, 11 (19): 3405- 3412.

[19] Hussain I. and Uddin M. B. 2012. Optimization effect of germination on functional properties of wheat flour by response surface methodology. International Research Journal of Plant Science. 3 (3): 031-037.

[20] Aremu MO, Olaofe O, Akintayo ET. Functional properties of some Nigerian varieties of legume seed flour concentration effect on foaming and gelation properties. J Food Technol. 2007; 5 (2): 109-115

[21] Adeleke, R. O. and Odedeji, J. O. (2010). Functional properties of wheat and banana flour blends. Pakistan Journal of Nutrition. 9: 535-538.

[22] Bojňanská, T., Frančáková, H., Líšková, M. and Tokár, M. (2012). Legumes - The alternative raw materials for bread production. Journal of Microbiology, Biotechnology and Food Sciences. 1 (February Special issue): 876-886.

[23] Bose, D. and Shams-Ud-Din, M. (2010). The effect of chickpea (Cicer arietinim) husk on the properties of cracker biscuits. Journal of Bangladesh Agril. Univ. 8: 147-152.

[24] Chin, N. L., Mohd Jusoh, Y. M., Yusof, Y. A. and Abdul Rahman, R. (2009). Bread crust thickness measurement using digital imaging and $\mathrm{L} \mathrm{a} \mathrm{b}$ color system. Journal of Food Engineering. 94: 366-371.

[25] Emaga, T. H., Andrianaivo, R. H. Wathelet, B. Tchango, J. T. and Paquot, M. 2008. Effects of the stage of maturation and varieties on the chemical composition of banana and plantain peels. Food Chemistry, 103: 590-600. 
[26] Eissa, H. A., Hussein, A. S. and Mostafa, B. E. (2007). Rheological properties and quality evaluation of egyptian balady bread and biscuits supplemented with flours of ungerminated and germinated legume seeds or mushroom. Polish Journal of Food and Nutrition Sciences. 57 (4): 487496.

[27] Ethiopian Health and Nutrition Research Institute (EHNRI). 2009/2010. Nutrition Baseline Survey: Report for the National Nutrition Program of Ethiopia. Addis Ababa. Ethiopia.

[28] Okoye,. J. I and Mazi, E. A. 2011. A development and quality evaluation of soy-fortified custard. Journal of Environment, Science and Technology 1: 99-104.

[29] Mahgoub S. E. O., Nnyepi M. and Bandeke T. 2006. Factors affecting prevalence of malnutrition among children under three years of age in Botswana. African Journal of Food, Agriculture, Nutrition and Development. 6 (1): 1-25.

[30] Dewey, K. G. and Brown, K. H. 2003. Update on Technical Issues Concerning Complementary Feeding of Young Children in Developing Countries and Implications for Intervention Programs. Food Nutrition Bulletin 24: 5-28.

[31] Dejene Dida. 2010. Study on the effect of traditional processing on proximate composition and bioavailability of minerals in chickpea (Cicer arietinum) grown in Ethiopia. MSc Thesis, Addis Ababa University, Addis Ababa. 80pp.

[32] Meseret Bekele. 2011. Effect of fermentation on Quality Protein Maize-soybean blends for the production of weaning food. MSc Thesis, Addis Ababa University, Addis Ababa. 128pp.

[33] FAOSTAT (2011). http://faostat.fao.org/site/567/DesktopDefault.aspx. (Accessed 12th December 2011).

[34] Gundu, R., Thorat, I. D., Jagtap, D. D., Datta, A. K. and Jayashree, G. C. (2012). Optimization of Cup Bread Baking in Household Electric Oven. Global Advanced Research Journal of Food Science and Technology. 1 (5): 074-080.
[35] Hefnawy, T. M. H., El-Shourbagy, G. A. and Ramadan, M. F. (2012). Impact of adding chickpea (Cicer arietinum L.) flour to wheat flour on the rheological properties of toast bread. International Food Research Journal. 19 (2): 521-525.

[36] Faber M., Laurie S. and Van Jaarsveld P. 2008. Nutrient content and consumer acceptability for different cultivars of orange-fleshed sweet potato. South African Sugar Association Project no 202: 40pp.

[37] Muhimbula H. S., Issa-Zacharia A. \& Kinabo J. 2011. Formulation and sensory evaluation of complementary foods from local, cheap and readily available cereals and legumes in

[38] Norhaizan ME \& Nor Faizadatul Ain AW., 2009. Determination of Phytate, Iron, Zinc, Calcium Contents and Their Molar Ratios in Commonly Consumed Raw and Prepared Food in Malaysia. Mal J Nutr 15 (2): 213 - 222.

[39] Inyang C. U. and Zakari U. M. 2008. Effect of Germination and Fermentation of Pearl Millet on Proximate, Chemical and Sensory Properties of Instant "Fura"- A Nigerian Cereal Food. Pakistan Journal of Nutrition. 7 (1): 9-12.

[40] Maxson, E. D., Rooney, L. W. 1972. Evaluation of methods for tannin analysis in sorghum grain. Cereal Chem. 49: 719-729.

[41] Abioye V. F., Ade-Omowaye B. I. O., Babarinde G. O. and Adesigbin M. K. 2011. Chemical, Physico-chemical and sensory properties of soy-plantain flour. African Journal of Food Science. 5 (4): 176-189.

[42] Gernah D. I., Ariahu C. C. \& Ingbian E. K. 2011. Effects of malting and lactic fermentation on some chemical and functional properties of maize (Zea mays). American Journal Food Technology. 6 (5): 404-412.

[43] Tafesse Bosha. 2011. Development of Cereal-based Complementary Food using Locally Available Food Items. MSc Thesis, Hawassa University, Addis Ababa. 103pp.

[44] International Food Policy Research Institute. 2005. An assessment of the causes of malnutrition in Ethiopia. Washington, DC, USA. 